American Journal of Applied Sciences 5 (7): 891-895, 2008

ISSN 1546-9239

(C) 2008 Science Publications

\title{
Hydrochemical Differentiation of Salinisation Process of the Water in Endoreic Semi-Arid Basin: Case of Rémila Basin, Algeria
}

\author{
${ }^{1,2}$ Houha Belgacem, ${ }^{3}$ Kherici Nacer, ${ }^{4}$ Kachi Slimane and ${ }^{5}$ Valles Vincent \\ ${ }^{1}$ Avignon Hydrogéology Laboratary, Avignon University, France \\ ${ }^{2}$ Department of Biology, Khenchela University, Algeria \\ ${ }^{3}$ Department of Hydrogeology, Faculty of Earth Sciences and Agronomy, \\ Annaba University, Algeria \\ ${ }^{4}$ Department of Civil Engeneering and Hydraulic, Faculty of Sciences, \\ Guelma University, Algeria \\ ${ }^{5}$ Avignon Hydrogéology Laboratary, Avignon University, France
}

\begin{abstract}
The aim of this study is to determine and treat a hierarchical basis of the various mechanisms responsible for the space variation of the water quality in a endoreic semi-arid basin. The water chemistry showed a large variability in space and time. The total dissolved solid (TDS) in water increases from upstream to downstream due to the effect of the arid climate, but also due to the waterrock interactions and the anthropic polution of surface water. The water chemistry changes progressively from bicarbonate calcic upstream to sulphated and chlorinated calcic in the median zone to chlorinate sodic in the Sebkha. Thermodynamic modelling showed the major role of evaporation in the evolution of the water chemistry. The result indicated calcite precipitation then gypsum precipitation as well as cations exchanges reactions. Statistical approach allowed to arrange processes that responsible for the hydrochemical variability according to their important. The increase of water salinity is due mainly to the aridity process. The differentiation between salty surface water (Sebkha) and deeper water (Chott) is the second process. The combined of the geochemical and statistical methods allowed to identify the main variability sources of the water composition and to classify them in this complex system.
\end{abstract}

Key words: Hydrochemistry, statistics, aridity, Sebkha, Chott, Algeria

\section{INTRODUCTION}

The hydrochemistry of the semi-arid endoreic zones is marked by the phenomena of concentration of the solutions and salinisation under the influence of the evaporation. In this context, the other mechanisms responsible for the acquisition of the chemical quality of water are masked by the factor concentration ${ }^{[1,2]}$ To appreciate the variety of mechanisms responsible for hydrochemical variations requires the identification and the hierarchical organization of the processes.

The mechanisms that responsible for the variation of water composition are often numerous and complex and depends on the geology, climatic and anthropology. The objective of this work is to study the geochemistry of ground water in the endoreic basin of Rémila in order to put in evidence the processes which affect the quality of water and finally to organize them by coupling the geochemical and statistical approaches.
Presentation of the study zone: The endoreic basin of Rémila is located between the Atlas Tellien in the North and the Saharan Atlas in the South (Fig. 1). It is delimited to the North by Djebel Fedjoudj, to the South by Aures massif, to the West by Djebel Amrane and to the East by Sebkha. The massifs encircling that exceed $1000 \mathrm{~m}$ and peak in $2300 \mathrm{~m}$ at the top of Aures (Djebel Chélia). The low zone has a height of $830 \mathrm{~m}$.

The climate is Mediterranean semi-arid ${ }^{[3]}$, the annual average of the precipitation is $330 \mathrm{~mm}$ and of the temperatures is $16^{\circ} \mathrm{C}$. The potential evaporation of Penman is $1400 \mathrm{~mm}^{[4]}$. The river system is essentially formed by oued Bou el Freis and El-Gueiss that contribute to the recharge of the aquifer ${ }^{[4]}$.

Geology and hydrogeology: The Trias appears in the Southeast in the diaper of Khenchela and the limestone of the Cretaceous to the South and the North of the basin (Fig. 1). The sandstone of the Miocene is transgressed on the Cretaceous. The Quaternary is 
Am. J. Applied Sci., 5 (7): 891-895, 2008

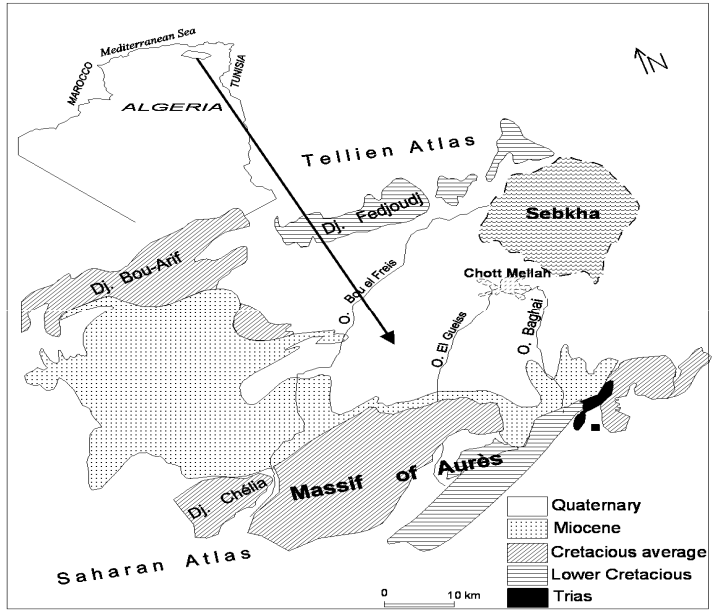

Fig.1: Geographic and geologic map of Rémila basin

formed by detritus formations that accumulated in the centre of the plain and based on a marly substratum.

The geometry of the Mio-plio-quaternary reservoir depends on the nature of sediment deposits that passes $280 \mathrm{~m}$ of thickness in the centre of the plain ${ }^{[4]}$.

The organisation of these deposits in sedimentary sequence, favoured the existence of the preferential horizon of water flow, characterized by an extreme lateral and vertical heterogeneity. The recharge of the basin is directly insured by the precipitation and by the side contributions of the Cretaceous and Miocene. The general drainage of water flows within a direction West-East. The permeability varies from $10^{-3} \mathrm{~m} \cdot \mathrm{s}^{-1}$ to $10^{-7} \mathrm{~m} \cdot \mathrm{s}^{-1}$, with an average of $10^{-5} \mathrm{~m} \mathrm{sec}^{-1}{ }^{[3,4]}$.

\section{MATERIALS AND METHODS}

The water analyses were classified according to the increasing contents in chloride, witch considered as conservative element so can be used as hydrochemical tracer. The behaviour of the various major elements is studied by means of diagrams of concentration based on the ion chlorinate as factor of concentration $(\mathrm{FC})^{[5,6,7,8,9]}$.

The calculation of the balance states with regard to main salts that can be precipitated into this environment was realized with the model of Ionic association "Aqua" ${ }^{,[10]}$. The chemical activity is calculation from the concentrations by using the law of Debye-Hückel. This model has already widely tested on numerous salty ground $\mathrm{s}^{[11,12,13,14]}$. The $\mathrm{pH}$, the temperature and the redox potential (Eh) was measured in the field. The balancing partial pressure of carbon dioxide $\left(\mathrm{pCO}_{2}\right)$ was calculated from the measure of the $\mathrm{pH}$ and the alkalinity carbonate ( Alcc).

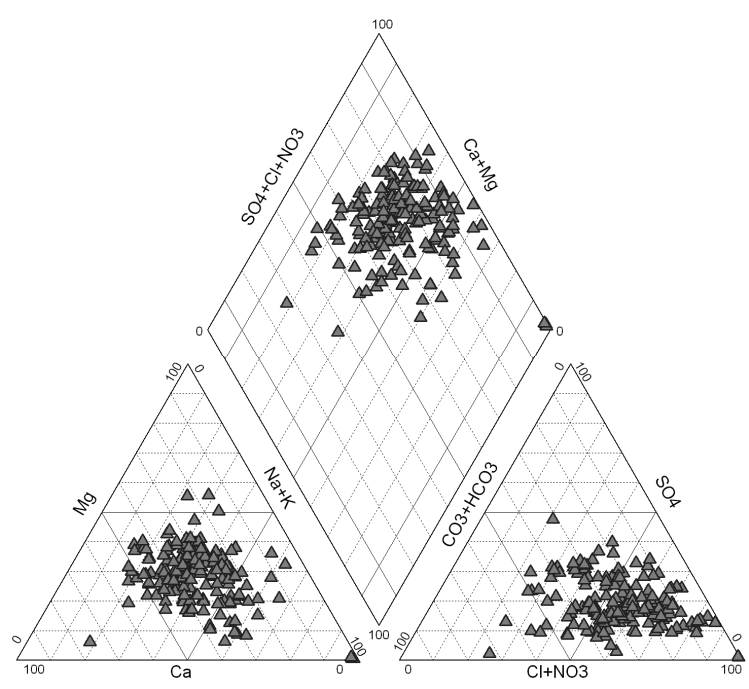

Fig. 2: Piper diagram for water of Rémila basin
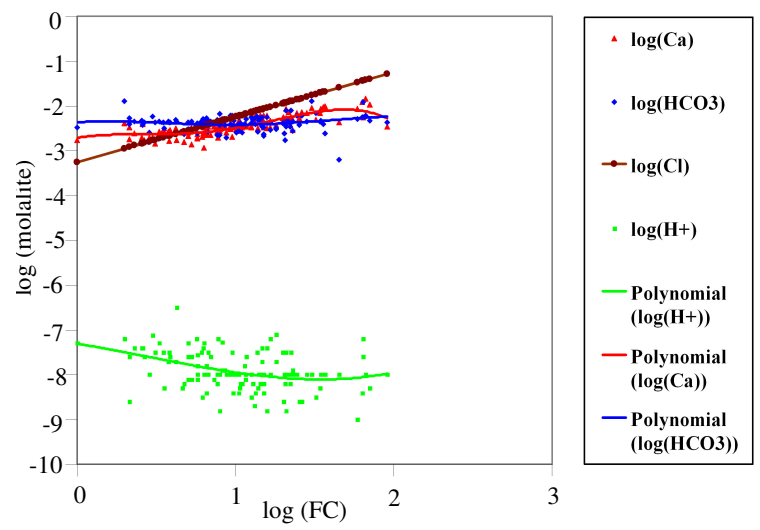

Fig. 3: Diagram of concentration of $\mathrm{HCO}_{3}, \mathrm{Ca}$ and $\mathrm{Cl}$

Concept of residual alkalinity calcite ${ }^{[15]}$ : Applied to the forming of the calcite (RA calcite) then some gypsum (RA calcite+gypsum) was used to verify the equivalence between the chemicals evolutions under the influence of the evaporation and the chemical composition of solutions

RAcalcite $=$ Alkalinity - Calcium total $\left(\mathrm{moL}\right.$ litre $\left.^{-1}\right)$

\section{RESULTS AND DISCUSSION}

The diagram of Piper (Fig. 2) shows an evolution of the chemical facies from bicarbonate-calcic in the South to chloride sodic near the Sebkha. In the median zone, the facies of water is sulphate and chloride calcic.

Diagram of concentration: The element concentration diagram (based on the ion $\mathrm{Cl}^{-}$) is presented in (Fig. 3 and 4). The FC corresponds to the value in 
Am. J. Applied Sci., 5 (7): 891-895, 2008

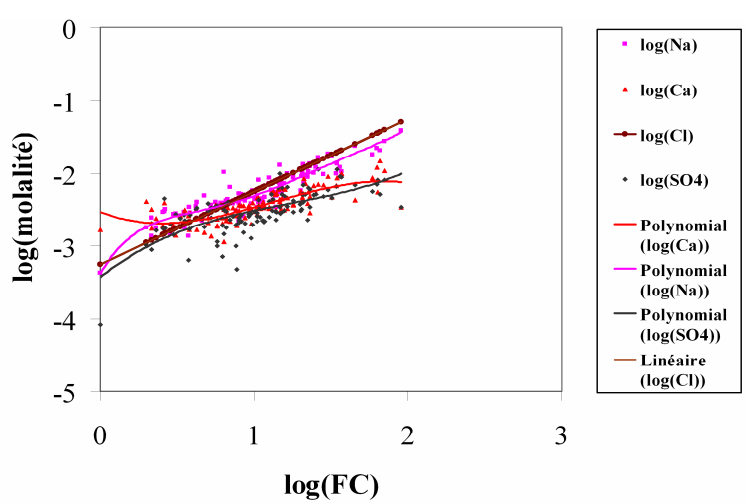

Fig. 4: Diagram of concentration of $\mathrm{Ca}, \mathrm{Na}, \mathrm{SO}_{4}$ and $\mathrm{Cl}$

chloride of the sample divided by the value into chloride of the most diluted sample.

The sodium: In diluted water, $\log (\mathrm{FC})$ varies from 0 to 0.5 , the concentration of sodium $\left(\mathrm{Na}^{+}\right)$increases, but slightly less quickly than chloride (Fig. 4). For more concentrated water, log (FC) lies between 0.5 and 1.5, the content of $\mathrm{Na}^{+}$evolves in a similar way of $\mathrm{Cl}^{-[16,17]}$. This is probably due to a fixation of $\mathrm{Na}^{+}$by the capacity of cationic exchange $(\mathrm{CEC})^{[18]}$.

The alkalinity: In diluted waters, $\log (\mathrm{FC})$ understood between 0 and 0.5 , the alkalinity decreases and then stabilized (Fig. 3). Beyond log (FC) superior to 0.5, we note an important dispersal of points. The alkalinity decreases and the content in $\mathrm{Ca}^{2+}$ increase (less than the chloride) towards the heights values of FC. This evolution suggests a precipitation of calcite with $\mathrm{Ca}^{2+}$ dominating Alcc, from witch we conclude an negative RA calcite ${ }^{[6,7,8]}$. The state of saturation of the solutions towards the calcite will allow us to confirm this hypothesis. The dispersal of the alkalinity results mainly from the spatial variability of $\mathrm{pCO}_{2}$, connected to the gas exchanges between waters and their environment $^{[5,16]}$.

The pH: The $\mathrm{pH}$ is stable (Fig. 3). This is in agreement with an evolution in the neutral salt way ${ }^{[19]}$. The strong dispersal of points must be attributed to the spatial variability of the $\mathrm{pCO}_{2}$.

The calcium: The concentration of $\mathrm{Ca}^{2+}$ increase more quickly than the alkalinity but slightly less than the tracer (Fig. 3). This process is in agreement with the precipitation of the calcite in this geochemical context. Besides the concentration under the influence of the evaporation, the phenomena of exchanges of cations between clay-humic complex and the solution of the ground surface increase the desorption of $\mathrm{Ca}^{2+}$ during

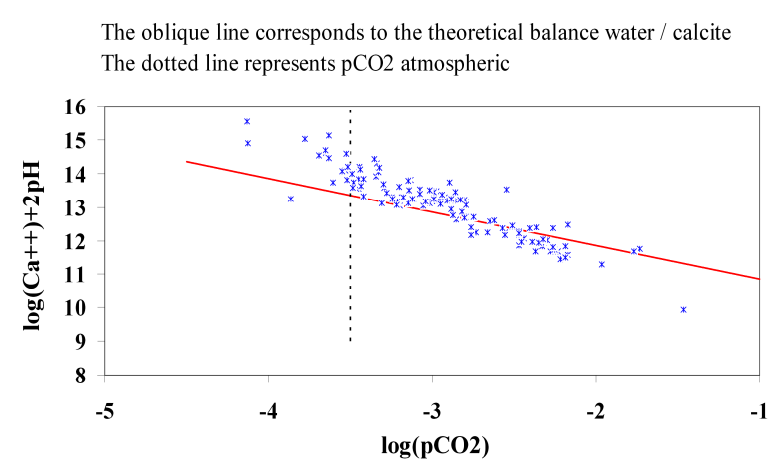

Fig. 5: Diagram of balance of the solutions with the calcite

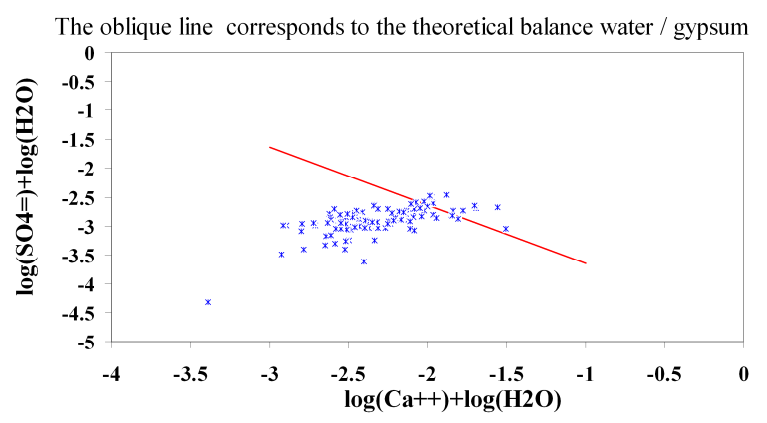

Fig. 6: Diagram of balance of the solutions with the gypsum

the concentration of the solutions due to absorption of the sodium ${ }^{[20,21]}$. For $\log (\mathrm{FC})=1.7, \mathrm{Ca}^{2+}$ is stable. It can be affected by the successive precipitation of calcite and gypsum.

The sulphate: $\mathrm{SO}_{4}^{-2}$ increases, less quickly than $\mathrm{Cl}^{-}$ (Fig. 4) until the value of $\log (\mathrm{FC})=1,7$; beyond this value, $\mathrm{SO}_{4}^{-2}$ seems to be controlled by the precipitation of gypsum.

Balances minerals-solutions: The diagram of concentration leads us to various hypotheses on reactionnels mechanism: precipitation of calcite, precipitation of calcite and gypsum, Practically, all the waters are in balance or supersaturated towards the calcite (Fig. 5). The forming of this mineral can explain the control of calcium and the alkalinity in solution ${ }^{[1,6,7]}$.

Concerning the state of balance with regard to the gypsum, the solution aims towards the balance (Fig. 6). The forming of this mineral thus controls the sulphates ions. In conclusion, these two results confirm the hypotheses advanced from the study of the diagrams of concentration.

Statistical multivariées analyses: The principal components analysis (ACP) was applied to discriminate, the factors which influence most the 
Am. J. Applied Sci., 5 (7): 891-895, 2008

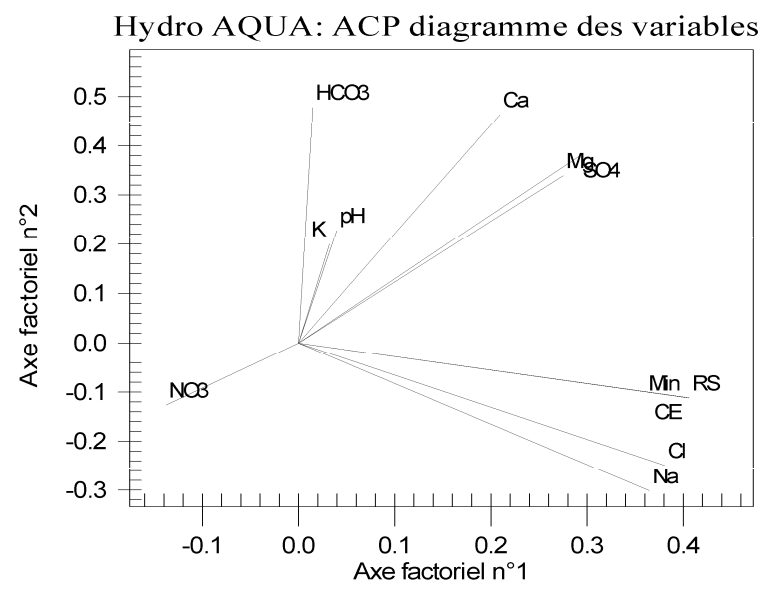

Fig. 7: ACP of water Rémila basin (Space of the variables)

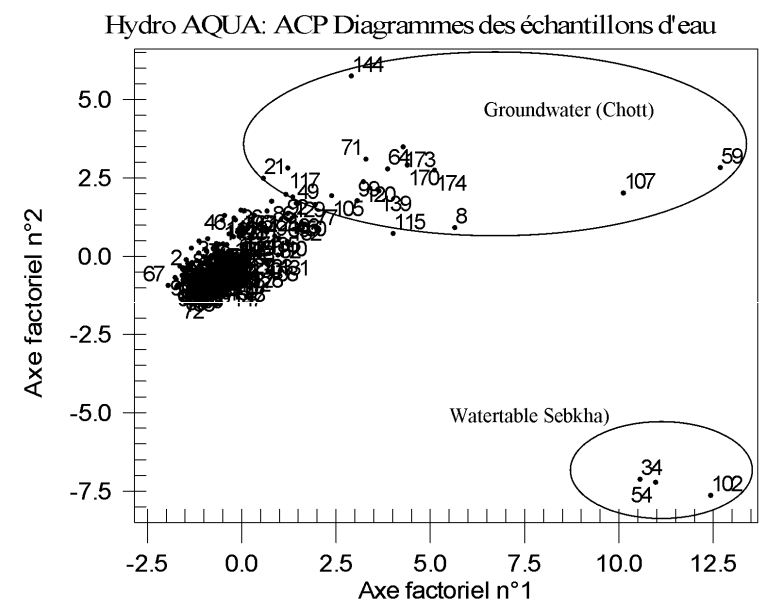

Fig. 8: ACP of water Rémila basin (Space of the individuals)

variability and the hydrochemical classes ${ }^{[22,23]}$ then to organize them according to their important order.

Geochemical analyse: The results of the principal component analysis (ACP) concerned twelve physic-chemical parameters: $\mathrm{Ca}^{2+}, \mathrm{Mg}^{2+}, \mathrm{Na}^{+}, \mathrm{K}^{+}$, $\mathrm{Cl}^{-}, \mathrm{SO}_{4}{ }^{-2}, \mathrm{NO}_{3}, \mathrm{HCO}_{3}^{-}$, electric specific conductivity (IT), mineralization (Min), dry residue ( $\mathrm{RS}$ ) and $\mathrm{pH}$ that carried out on 174 samples (drillings, well, Chott and Sebkha) is presented in (Fig. 6, 7 and 8).

The factorial axis I (Fig. 7) expresses $49 \%$ of the variance. This axis indicates the concentration of the solutions. The axis II express $17 \%$ of the variance and oppose variables such as $\mathrm{HCO}_{3}{ }^{-}, \mathrm{Ca}^{2+}, \mathrm{SO}_{4}^{-2}$ to $\mathrm{Na}^{+}$and $\mathrm{Cl}^{-}$. This axis defined two opposed hydrochemical systems: surface water (Sebkha) against ground water

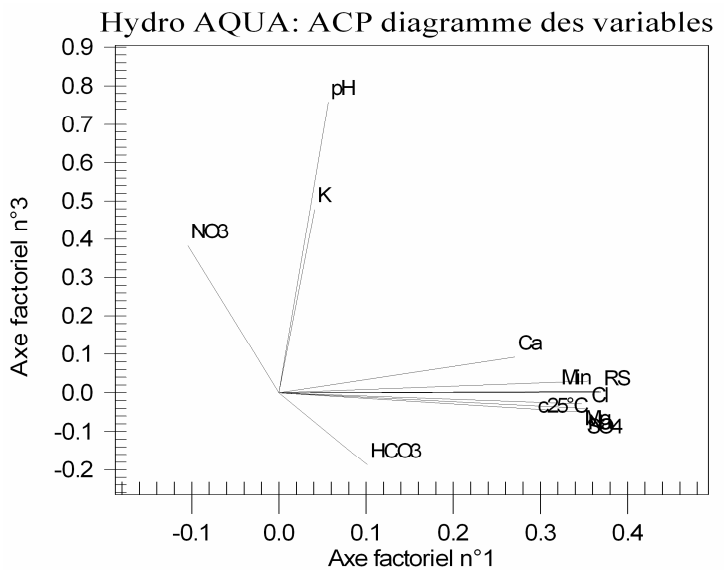

Fig. 9: ACP of water Rémila basin (Space of the variables)

(Chott). (Fig. 7 and 8). The axis III (Fig. 9) represents 9 $\%$ of the variance and groups together the variables $\mathrm{K}^{+}$, $\mathrm{NO}_{3}{ }^{-}$and $\mathrm{pH}$. This axis translates the anthropogenic pollution (agricultural or urban).

\section{CONCLUSION}

This study shows the interest of the coupling between the geochemical and statistical approaches (ACP) for the analysis of the chemical composition of water in a semi-arid endoreic complex system.

In Rémila basin, the salinisation is the main process and its importance masked the other sources of chemical variability. In that case, the associated mechanisms are: calcite, gypsum precipitation and anthropogenic pollution.

The use of the statistical methods (ACP), allows us to identify the others processes and to classify them. The study underlines the hydrochemical differentiation between the salt evolution of surface waters (Sebkha) and ground water (Chott) in the same hydrochemical region.

\section{REFERENCES}

1. Ouardi, D., 2006. Degradation of ground and aquifer of the irrigated perimeter by Moroccan Tadla by salinisation and sodisation. Doctoral thesis, university of Avignon.

2. Vallès, V., M. Rezagui, L. Auque, A. Semadi, L. Roger and H. Zougari, 1997. Geochemistry of saline soils in two arid zones of the Mediterranean basin. I. Geochemistry of the Chott MelghirMerouane watershed in Algerie. Arid soil research and rehabilitation, 11: 71-84. 
3. Houha, B., 1996. Quantity and quality of ground water of the region of Khenchela (Garaât and Tarf). Thesis of magister, university of Annaba, pp: 114.

4. Direction départementale des travaux publics de Batna (DTPB). Study by prospecting geophysics in the plain of Rémila-Khenchela. Batna: DTPB, 969.

5. Daoud, D., 1995. Geochemical characterization and isotopique of the ground water and estimation of the rate of evaporation in the Chott Chergui basin (semi-arid zone), Algeria. Doctoral thesis, university of Paris-South centres of Orsay.

6. Gueddari, M., 1980. Géochimie des sels et des saumures du Chott El-Jerid. Thèse de $3^{\mathrm{e}}$ cycle, université de Tououse, pp : 131.

7. Vallès, V., M. Rezagui, L. Auque, A. Semadi, L. Roger and H. Zougari, 1997. Geochemistry of saline soils in two arid zones of the Mediterranean basin. I. Geochemistry of the Chott MelghirMerouane watershed in Algerie. Arid soil research and rehabilitation, 11: 71-84.

8. Al-Droubi, A., 1976. Géochimie des sels et des solutions concentrées par évaporation. Modèle thermodynamique de simulation. Application aux sols salés du Tchad. Mem. Sci. Geol., 46:1-17.

9. Gueddari, M., 1980. Géochimie des sels et des saumures du Chott El-Jerid. Thèse de doctorat $3^{\text {è }}$ cycle, université de Tououse, pp: 131.

10. Bahri, 1982. Use of waters and grounds salted in the plain of Kairouan Tunisia. Thesis of 3rd cycle, CRGR.

11. Vallès, V. and A.M. De Cockborne, 1992. Elaboration d'un logiciel de géochimie appliquée à l'étude de la qualité des eaux. Dans: altération et restauration de la qualité des eaux continentales, pp: 27-30.

12. Valles, V., M.K. N'Diaye, A. Bernadac and Y. Tardy, 1989. Geochemistry of water in the Kouroumari region, Mali. $\mathrm{Al}, \mathrm{Si}$ and $\mathrm{Mg}$ in water concentrated by evaporation: development of a model. Arid Soil Research and Rehabilitation, 3: 21-39.

13. Marlet, S., V. Valles and L. Barbiero, 1996. Field study and simulation of geochemical mechanisms of soil alkalinisation in the sahelian zone of Niger. Arid soil research and rehabilitation, 10: 243-256.
14. Chernet, T., Y. Travi, V. Valles, 2001. Mechanism of degradation of the quality of natural water in the lakes region of the Ethiopian rift valley. Water Ressources,35: 2819-2832.

15. Barbiero, L., J.P. Queiroz Neto and G. Ciornei et al., 2002. Geochemistry of water and ground water in the Nhecolândia, Pantanal of Mato Grosso, Brazil: variability and Associated processes. Wetlands, 22: 528-540.

16. Al Droubi, A., B. Fritz, J.Y. Gac and Y. Tardy, 1980. Generalized residual alkalinity concept; Application to prediction of the chemical evolution of natural waters by evaporation. Am. J. Sci., 280: 560-572.

17. Dosso, M., 1980. Géochimie des sols salés et des eaux d'irrigation. Aménagement de la basse vallée de l'Euphrate en Syrie. Thèse de doctorat, université de Toulouse.

18. Vallès, V., 1987. Modélisation des transferts d'eau et de sel dans un sol argileux. Application aux calculs des doses d'irrigation ; mém des Sci Géol, $79: 1-148$.

19. Gallali, T., 1980. Transfert sels matière organique en zones arides méditerranéennes. Thèse de doctorat $3^{\text {è }}$ cycle, université de Nancy I.

20. Boivin, P., F. Brondeau, M. Dosso and M. Kuper, 2000. Lutte contre la désertification: problématique générale des zones irriguées. Stratégie française de l'eau agricole pour le développement Paris.Ministère des affaires étrangères.

21. Shainberg, I., J.D. Oster and J.D. Wood, 1980. Sodium-Calcium exchange in montmorillonite and illite. SSSAJ, ; 5: 860-964.

22. Evangelou, V.P. and J. Lumbanraja, 2002. Ammonium-Potassium-Calcium exchange on vermiculite and hydroxyl-aluminium vermiculite. SSSAJ., 66: 445-455.

23. Melloul, A. and M. Collin, 1992. The principal component statistical method as a complementary approach to geochemical methods in water quality factor identification; application to the Coastal plain aquifer of Israel. J. Hydrol., 140: 49-73.

24. Morell, E., M. Giménez and V. Esteller, 1996. Application of principal components analysis to the study of salinization on the Castellon Plain (Spain). J. Sci. Total Envir., 177: 161-17. 